\title{
Zarządzanie materiałami wizualnymi na portalach społecznościowych \\ Przypadek portalu www.nasza-klasa.pl
}

\section{Wprowadzenie}

Doniższy raport badawczy dotyczy badania ilościowego nad próbą stu użytkowników portalu www.nasza-klasa.pl. Obrane zmienne to płeć i wiek. Badanie zostało przeprowadzone za pomocą ankiety elektronicznej. Zawiera ona zestaw dwudziestu dwóch pytań, których celem jest pomiar zaangażowania użytkownika portalu społecznościowego (w tym przypadku - www.nasza-klasa.pl) w kreowanie swojej tożsamości wirtualnej za pomocą zdjęć'.

Przebadana została grupa 100 osób, podzielona ze względu na dwie podstawowe zmienne - wiek i płeć. Miejsce zamieszkania ankietowanych lub ich wykształcenie uznano za nieistotne z punktu widzenia kreacji wizerunku za pomocą materiałów wizualnych. Próbę podzielono na dziesięć przedziałów wiekowych. Jednostki poddane badaniu umieszczono w następujących grupach - od 13 do 16 roku życia, dalej od 16 do 19, od 19 do 24, od 25 do 40 oraz od 41 do 59 roku życia w przypadku kobiet i od 41 do 64 w przypadku mężczyzn. Grupy wiekowe są ustalone w sposób wzorcowy względem trybu edukacji możliwego w Polsce. Przedział od lat 13 do 16 dotyczy młodzieży uczęszczającej do szkoły gimnazjalnej, przedział od 16 do 19 lat nawiązuje do młodzieży objętej edukacją ponadgimnazjalną,

1 Pytania zastosowane w badaniu, http://www.moje-ankiety.pl/wypelnij/kwestionariusz/13778, 25.04.2010. 
a przedział od 19 do 24 roku życia modelowo dotyczy studentów. Wiek 16 i 19 lat stanowi zarazem początek i koniec grupy wiekowej, gdyż w tym wieku następuje zmiana szkoły. Problem ten został rozwiązany w sposób następujący - wybierając uczestników badania w przedziale od 13 do 16 roku życia, istotna była ich deklaratywna przynależność do szkoły gimnazjalnej. Analogiczne postępowanie zastosowano w przypadku grupy od 16 do 19 lat (uczęszczanie do szkoły ponadgimnazjalnej). Przedział od 25 do 40 roku życia dotyczy osób, które zgodnie z założonym modelem ukończyły studia wyższe i rozpoczęły pracę. Przedział od lat 41 do progu wieku emerytalnego uznano za okres względnej stabilizacji życiowej. Początkowo zamierzano przebadać grupę użytkowników, którzy są (zgodnie z założeniem) emerytami, jednakże próba pomiaru okazała się trudna do przeprowadzenia. Wysłane ankiety osiągnęły najniższy stopień odpowiedzi - otrzymano po dwie ankiety dla każdej z płci w tym przedziale. Dodatkową trudnością okazał się fakt, że w toku poszukiwań losowo wybranych osób można było zauważyć, jak bardzo nieliczna jest to grupa - przykładowo z Warszawy deklaratywnie pochodzi 29 użytkowników o imieniu Władysław ${ }^{2}$. Natomiast kobiet o imieniu Anna z tego samego miasta jest 257, jednakże w przedziale od 13 do 16 roku życia ${ }^{3}$.

\section{Reakcje respondentów}

Badanie opinii na temat zarządzania materiałami wizualnymi na portalu społecznościowym www.nasza-klasa.pl przeprowadzono, wysyłając prośby o wypełnienie ankiety (dostępna za pomocą linku) do wybranych użytkowników. Potencjalni respondenci zostali wyłonieni najczęściej za pomocą wyszukiwarki, dostępnej na samym portalu. Przykładowo: wpisane zostało imię - Tomasz, miasto - Toruń, a także określony przedział wiekowy. Wyniki wszystkich grup wiekowych otrzymano w przeciągu trzech tygodni od wysłania pierwszej serii wiadomości. Początkowo wysłano 100 próśb, proporcjonalnie do obranej próby, jednakże aby przyspieszyć etap zbierania danych, sukcesywnie zwiększano liczbę osób, do których zwró-

2 http://nasza-klasa.pl/szukaj/profile?q=w\%C5\%82adys\%C5\%82aw\&city=warszawa\&gender=\&min_age=65\&max_age=\&szukaj.x=0\&szukaj.y=0, 4.04.2010.

${ }_{3} \mathrm{http}: / /$ nasza-klasa.pl/szukaj/profile?q=anna\&city=warszawa\&gender=\&min_age$=13 \&$ max_age $=16 \&$ szukaj.x=49\&szukaj.y=3, 4.04.2010. 
cono się z prośbą o wypełnienie ankiety. Tabela 1 przedstawia liczebność wysłanych próśb o uczestnictwo w badaniu. Ostatecznie wysłano 245 wiadomości (nie licząc 20 próśb wysłanych do kobiet od 60 roku życia oraz mężczyzn od 65 roku życia). Jak wykazuje tabela 1, najszybciej pełny wynik otrzymano od mężczyzn w grupie wiekowej 25-40 lat. Najmniej zainteresowani uczestnictwem w badaniu okazali się mężczyźni od 41 do 64 roku życia, do których wysłano aż 73 wiadomości.

Tabela 1. Najchętniej uczestnicząca w badaniu grupa wiekowa

\begin{tabular}{|l|c|}
\hline \multicolumn{1}{|c|}{$\begin{array}{c}\text { Najchętniej uczęstnicząca } \\
\text { grupa wiekowa }\end{array}$} & $\begin{array}{c}\text { Liczba wysłanych } \\
\text { wiadomości }\end{array}$ \\
\hline 1. Mężczyźni 19-24 & 12 \\
\hline 2. Kobiety 19-24 & 13 \\
\hline 2. Kobiety 25-40 & 13 \\
\hline 3. Mężczyźni 25-40 & 14 \\
\hline 4. Kobiety 16-19 & 16 \\
\hline 5. Kobiety 41-59 & 18 \\
\hline 6. Kobiety 13-16 & 22 \\
\hline 7. Mężczyźni 13-16 & 32 \\
\hline 7. Mężczyźni 16-19 & 32 \\
\hline 8. Mężczyźni 41-64 & 73 \\
\hline SUMA & 245 \\
\hline
\end{tabular}

Źródło: opracowanie własne.

W toku omawianego etapu procesu badawczego pojawiały się interakcje o zróżnicowanym charakterze. Respondenci grupy wiekowej 41-59/41-64 oraz ci w wieku emerytalnym odpowiedzieli na prośbę o wypełnienie ankiety. W niemalże wszystkich przypadkach była to krótka informacja o chęci uczestniczenia w badaniu czy zwyczajne pozdrowienia. Kilka osób wysłało także życzenia świąteczne (pierwszą serię ankiet wysłano tuż przed świętami Wielkiej Nocy). Ponadto jedna z potencjalnych respondentek przysłała wiadomość ze szczegółowym opisem członków swojej rodziny, inna z kolei przeprosiła za opóźnienie w partycypacji, szczegóło- 
wo je tłumacząc. Kilka osób (nieznanych autorce projektu) zaprosiło ją do grona znajomych (na www.nasza-klasa.pl). Nawiązując do wspomnianego wątku rezygnacji z grupy wiekowej powyżej progu emerytalnego, miał on swoje umocowanie także w następującym przykładzie - jeden z panów wysłał wiadomość z informacją, że jego znajomość obsługi komputera jest tak niewielka, iż nie jest w stanie wypełnić ankiety. Oprócz wyżej opisanych interakcji, zdarzały się też propozycje spotkania lub pytania osobiste. Ten typ interakcji dotyczy głównie mężczyzn z przedziałów wiekowych: 13-16 i 16-19.

Pod koniec etapu zbierania danych, kiedy niektóre z wysłanych dziesięciu ankiet (przyp.: ankieta o takiej samej treści została wysłana do kobiet i mężczyzn w danej grupie wiekowej, dlatego powstało dziesięć odrębnych) stały się nieaktywne, pojawiły się sygnały ze strony chętnych do uczestniczenia. Jak już opisano w tabeli, ankiet wysłano więcej, niż potrzeba było faktycznie respondentów, aby uzyskać próbę. Powodem było realistyczne podejście do potencjalnych chęci uczestniczenia $w$ badaniu internetowym. Pomimo wysłania 245 wiadomości, etap zbierania danych trwał około trzech tygodni, wobec czego ogólną wolę partycypacji można ocenić jako niską. Nawiązując do rozpoczętego wątku - użytkownicy uprzednio poproszeni o udział w badaniu przysłali zapytania, dlaczego niemożliwe jest wypełnienie ankiety. Powodem takiego stanu rzeczy był fakt, że w momencie otrzymania założonych 10 ankiet, przykładowo względem kobiet od 24 do 40 roku życia, ręcznie zatrzymywano proces zbierania danych. Wobec tego kilkukrotnie autorka projektu była zmuszona do ponownego wysłania wiadomości do konkretnego użytkownika, głównie z przeprosinami za zaistniałą sytuację. Należy dodać, iż jest to główna wada ilościowych badań internetowych z ustaloną z góry próbą.

\section{Struktura raportu}

W celu uzyskania jak najwyższej czytelności poniższego raportu na wstępie należy wyłuszczyć kilka istotnych informacji. Zestawienie zostało podzielone ze względu na kategorie wiekowe. Omówienie rezultatu badania dla każdego z pytań rozpocznie się od prezentacji wyników zbadanych kobiet, następnie mężczyzn. Raport rozpocznie się od przedsta- 
wienia stanowisk względem zarządzania zdjęciami najmłodszej grupy wiekowej, zakończy zaś na najstarszej. Dane są przedstawione w sposób procentowy ze względu na istnienie pytań wielokrotnego wyboru. Ta forma zaprezentowania danych umożliwia również większą czytelność. W przypadku pytań jednokrotnego wyboru oczywisty jest fakt, że - przykładowo - 50\% badanych kobiet będzie stanowiło pięć osób (w danej grupie wiekowej), które konkretną odpowiedź zadeklarowały. Prezentację wyników dla pytań zamkniętych zakończy podsumowanie dla każdej grupy wiekowej.

W raporcie badawczym słowo profil i konto będą funkcjonować wymiennie. Przez pojęcie znajomi należy rozumieć użytkowników portalu www.nasza-klasa.pl, którzy stanowią osoby znane (a zatem dodane do grona Znajomi) konkretnemu respondentowi. Z kolei termin profil fikcyjny wskazuje na typ konta, które jest opisywane fałszywymi danymi lub odnosi się do postaci abstrakcyjnych (np. Święty Mikołaj). Ponieważ pytania zamknięte przeplatały się z pozostałymi rodzajami, zrezygnowano z ich numeracji. Wszelkie słowa lub frazy zapisane kursywą (tylko w niektórych, rozbudowanych zdaniach) stanowią dokładny cytat odpowiedzi (lub tylko jej części). Celem takiego zabiegu jest maksymalizacja czytelności poniższego raportu.

\section{Wyniki badania}

\subsection{Grupa wiekowa $13-16$ lat}

\subsubsection{Pytania zamknięte - kobiety i mężczyźni}

Najwięcej kobiet ma konto na portalu Nasza Klasa od 2 lat. Taka sama, znaczna część mężczyzn założyła swój profil w zeszłym roku (tj. 2009). Większość ankietowanych pań loguje się na swoim koncie od kilku do kilkunastu razy dziennie - za tymi dwiema częstotliwościami opowiedziało się $60 \%$ kobiet. Taka sama liczba mężczyzn wykonuje powyższą czynność kilka razy w tygodniu. Zdecydowana większość respondentek i respondentów posiada jeden album $w$ galerii. W przypadku ponad połowy kobiet jest ona zamknięta (galeria), natomiast wśród znaczącej części mężczyzn - otwarta. Respondentki w tej grupie wiekowej publikują od 6 do 10 zdjęć 
lub od 11 do 20 - te dwa przedziały liczbowe zadeklarowały po trzy ankietowane. Natomiast połowa mężczyzn, przy rozbiciu pozostałych głosów względem innych ilości, wybrała również przedział od 6 do 11 fotografii. W kwestii częstotliwości publikowania zdjęć wśród kobiet nie ma zdecydowanej większości. Z kolei połowa respondentów zadeklarowała, że wykonuje powyższą czynność kilka razy w roku. Panie zazwyczaj zamieszczają swoje zdjęcia - deklaracja ta wypłynęła od wszystkich respondentek. Niemalże identyczne wyniki zostały odnotowane wśród ankietowanych panów. Połowa kobiet wpisuje pod fotografią aforyzm, nieco mniej decyduje się na umieszczenie zabawnego sformułowania. Znaczna część panów deklaruje opisywanie za pomocą faktów lub, podobnie jak w przypadku pań, humorystycznych fraz. W kwestii publikacji zdjęć, na których respondenci prezentują się niekorzystnie, połowa kobiet takowych nie zamieszcza, nieco mniej z kolei nie potrafiło udzielić jednoznacznej odpowiedzi. Podobne proporcje, dla tych samych stanowisk, zostały zadeklarowane przez mężczyzn. Także zdecydowana większość z nich nie poddaje retuszowi swoich zdjęć. W przypadku wyników, jakie uzyskały dla tego pytania kobiety - głosy potwierdzające publikację retuszowanych fotografii i przeczące temu rozłożyły się równomiernie (po cztery ankietowane na tak i nie). Zdecydowana większość respondentów i respondentek odwiedza profile osób im nieznanych, przy czym część z nich robi to akcydentalnie (podczas poszukiwania znajomych użytkowników). Przy tym aż siedem respondentek nie podejmuje się komentowania zdjęć osób obcych. Z kolei ośmiu mężczyzn wykonuje powyższą czynność, ale w większości rzadko. Przy zapytaniu o istotność ocen, które są wystawiane zdjęciom respondentów, opinie rozłożyły się w miarę równomiernie - cztery ankietowane i pięciu ankietowanych odpowiedziało twierdząco, reszta przecząco. Podobne proporcje odpowiedzi uzyskało pytanie dotyczące tego, czy badani sami dokonują oceny fotografii osób im znanych. Wszystkie kobiety komentują zdjęcia znajomych, natomiast żadna z nich nie czyni tego zawsze. Na siedmiu mężczyzn, którzy oceniają fotografię znajomych, trzech nie robi tego wcale. $70 \%$ respondentek i $80 \%$ respondentów odwiedza profile wszystkich swoich znajomych, ze zróżnicowaną częstotliwością. Względem ostatniej kwestii, która została poruszona w badaniu, mianowicie, czy ankietowani akceptują publikację swoich zdjęć bez ich przyzwolenia, ponad połowa, zarówno kobiet, jak i mężczyzn, nie ma nic przeciwko temu. 


\subsubsection{Pozostałe pytania - kobiety}

Na pytanie o posiadanie konta fikcyjnego $30 \%$ kobiet odpowiedziało twierdząco. Jedna z pań nie uzasadniła, w jakim celu, druga wyjaśniła, że ma taką potrzebę. Trzecia respondentka poparła swoją odpowiedź stwierdzeniem, że chce jednocześnie odwiedzać inne profile bez wiedzy ich właścicieli, a także mieć możliwość kontrolowania, kto odwiedza jej profil. 70\% kobiet odpowiedziało przecząco. Ankietowane w większości uznały posiadanie konta fikcyjnego za pozbawione sensu, wobec czego nie mają potrzeby ich zakładania. Jedna z ankietowanych kobiet zaznaczyła, że jest to uzasadnione w przypadku takich postaci, jak Święty Mikołaj.

Kolejne pytanie dotyczyło kryteriów, jakimi respondentki w tej grupie wiekowej kierują się przy doborze zdjęć do publikacji. Odpowiedzią dominującą był atrakcyjny wygląd. Zaledwie jedna respondentka zadeklarowała, że nie stosuje żadnej określonej procedury w tym przypadku.

Na pytanie, czy ankietowanym kobietom podobają się zdjęcia ich znajomych, padały następujące odpowiedzi - 90\% odpowiedziało twierdząco, $10 \%$ przecząco. Pierwsze stanowisko zostało umotywowane faktem, że fotografie te są ciekawe, ładne, naturalne, zabawne, pokazuja pasje i, co ciekawe, sq ładnie wyretuszowane. Trzy respondentki nie uzasadniły wyboru odpowiedzi. Z kolei jedyne wyjaśnienie przeczące dotyczyło przekraczania granic dobrego smaku (dziewczyny wstawiaja zdjęcia, na których odkrywaja za dużo).

Znaczenie komentarzy dla kobiet w tej grupie wiekowej okazało się zróżnicowane. Zaledwie jedna respondentka zadeklarowała, że całkowicie nie mają dla niej znaczenia. Niektóre ankietowane stwierdziły, iż pomimo faktu, że komentarze nie są istotne, to cieszą się, gdy je otrzymują. Trzy badane kobiety zadeklarowały, że uwagi pod ich zdjęciami są bardzo ważne, inne z kolei uzależniły ważność komentarza od osoby, która zdecydowała się go zamieścić. Jedna respondentka stwierdziła, że są jej obojętne.

Na pytanie o znaczenie zdjęć w kontekście kreowania własnego wizerunku żadna $z$ ankietowanych nie zadeklarowała, że fotografie mają jakikolwiek wpływ na postrzeganie. 20\% kobiet udzieliło odpowiedzi przeczącej, argumentując, iż najpierw trzeba kogoś poznać, żeby wyrobić sobie konkretne zdanie o danej osobie. Z drugiej strony, jedna respondentka stwierdziła, że fotografie, w jej przypadku, nie mają wpływu na wizerunek, 
gdyż na swoim profilu umieściła tylko portret. Aż $80 \%$ ankietowanych kobiet nie potrafiło udzielić jednoznacznej odpowiedzi na to pytanie.

\subsubsection{Pozostałe pytania - mężczyźni}

Tylko dwóch mężczyzn, spośród ankietowanych w tej grupie wiekowej, posiada konto fikcyjne. Jeden $z$ respondentów zaniechał uzasadnienia, drugi z kolei ograniczył je do stwierdzenia: chcę posiadać. Pozostali ankietowani, mianowicie $80 \%$, motywowali swoje stanowisko brakiem czasu i potrzeby (przy czym trzech, spośród tych ośmiu ankietowanych, nie wpisało żadnej argumentacji).

Odpowiedzi na pytanie dotyczące kryteriów wyboru zdjęć do publikacji były w tej grupie wiekowej bardzo zróżnicowane. Jeden z respondentów uzasadnił, że o jego preferencjach w powyższym względzie nie decyduje nic konkretnego, drugi stwierdził, że wszystko. Do głównych powodów można zaliczyć: atrakcyjność i stosowność zdjęcia, a także rozpoznawalność respondenta w celu jego większej identyfikacji.

Dziewięciu respondentów przyznało, iż podobają im się fotografie opublikowane przez ich znajomych. Czterech z nich zaniechało uzasadnienia. Zarejestrowane argumenty oscylowały wokół atrakcyjności zdjęcia (zdjęcia: zabawne, fajne, ciekawe) i sympatii dla uwiecznionych nań znajomych. Jeden z ankietowanych mężczyzn stwierdził, że fotografie znajomych zyskują jego aprobatę, ponieważ ukazane na nich dziewczęta są półnagie.

Dla części respondentów umieszczane pod zdjęciem komentarze są ważne, dla innych nie. Jeden z ankietowanych wyraził zatroskanie kulturą wypowiedzi, jako znaczącą w kontekście odbioru osób uwiecznionych na fotografii. Pojawiły się również dwie deklaracje świadczące o niepoważnym podejściu do badania lub też znudzeniu - np. wpisanie w okno odpowiedzi przypadkowych liter.

Sześciu respondentów zadeklarowało, że zdjęcia mogą mieć wpływ na ich wizerunek (przy czym trzech nie uzasadniło swojego stanowiska). Głównym argumentem, przemawiającym za powyższym stwierdzeniem, jest to, że fotografie pozwalają na przegląd najważniejszych wydarzeń w życiu ankietowanych, przez co ujawniają informacje o nich samych i ich zainteresowaniach. Pozostali badani w tej grupie mężczyźni (tj. 40\%) nie zajęli jednoznacznego stanowiska. 


\subsection{Grupa wiekowa $16-19$ lat}

\subsubsection{Pytania zamknięte - kobiety i mężczyźni}

Większość kobiet nie pamięta, kiedy założyła konto, z kolei znaczna część mężczyzn uruchomiła je 2 lata temu. Połowa respondentów loguje się na swoim profilu kilka razy dziennie. Sześć respondentek wykonuje tę czynność każdego dnia, z różną częstotliwością. Osiemnastu na dwudziestu badanych w tej grupie wiekowej korzysta z tylko jednego albumu w galerii. W przypadku większości ankietowanych prowadzą oni galerię otwartą. Połowa respondentów umieściła w swoim albumie od 2 do 5 zdjęć. Najwięcej respondentek publikuje albo od 6 do 10 fotografii, albo między 21 a 50 (po trzy ankietowane na każdy z tych przedziałów). Ponad połowa mężczyzn i kobiet udostępnia swoje zdjęcia na profilu kilka razy w roku. Niemal wszyscy ankietowani w tej grupie wiekowej publikują zdjęcia, na których zostali uwiecznieni. Wśród kobiet często wybieranymi odpowiedziami były fotografie przedstawiające rodzinę, sympatię i spotkania. Niewiele mniej osób wybrało inne opcje, co świadczy o dużym zróżnicowaniu tematycznym zdjęć wśród respondentek w tej grupie wiekowej. Respondenci, oprócz odpowiedzi mnie samego, wybierali także opcję spotkania. Kobiety opisują swoje zdjęcia za pomocą aforyzmów (połowa) lub faktów (niemalże połowa). Prawie połowa mężczyzn do opisu fotografii używa tekstu piosenek lub skojarzeń z nią powiązanych. Warto zaznaczyć, że zadeklarowali oni odpowiedź samodzielną. Dziewczęta z kolei wpisują albo dedykację, albo aforyzm (połowa ankietowanych przypadająca na każdą z odpowiedzi). Niewiele mniej opisuje zdjęcia za pomocą faktów lub zabawnej frazy. Postawa względem publikacji zdjęć, na których respondenci, we własnym odczuciu, nie prezentują się najlepiej, jest zróżnicowana dla obu płci - rozkład głosów na każdą z odpowiedzi był dość równomierny. Większość pań zamieszcza zdjęcia, które są retuszowane. Taka sama, znaczna część panów odpowiedziała zarówno twierdząco, jak i przecząco na powyższe pytanie. Większość kobiet i mężczyzn w tej grupie wiekowej przegląda profile osób obcych. Jednakże ponad połowa ankietowanych nigdy nie komentuje zdjęć nieznajomych użytkowników. Zdecydowana większość respondentów (zarówno kobiet, jak i mężczyzn) nie uważa za istotne ocen ich fotografii. Podobna liczba ankietowanych zadeklarowała, że nie ocenia zdjęć swoich znajomych. Jednakże do sporadycznego ko- 
mentowania ich fotografii (czasami) przyznała się ponad połowa kobiet i jedna druga mężczyzn. Co się tyczy odwiedzin profili wszystkich znajomych ankietowanych, po trzy respondentki zadeklarowały odpowiedzi: raz na kilka miesięcy oraz wcale. Ta druga odpowiedź została również wybrana przez większość mężczyzn. Publikacja zdjęć bez zgody osoby na nich uwiecznionej spotkała się z akceptacją ponad połowy respondentów. $Z$ drugiej strony, taka sama liczba kobiet zadeklarowała brak przyzwolenia dla tej praktyki.

\subsubsection{Pozostałe pytania - kobiety}

Osiem na dziesięć respondentek nie ma konta fikcyjnego. Wśród argumentów dwa były dominujące - kobiety nie widzą potrzeby posiadania takiego profilu, a także uznają samą możliwość jego utworzenia za pozbawioną sensu.

Na pytanie dotyczące przesłanek, jakimi kierują się użytkowniczki portalu www.nasza-klasa.pl w tej grupie wiekowej, głównym uzasadnieniem publikacji fotografii jest jej niebanalność i ogólna atrakcyjność. Dwie respondentki uznały, że warunkiem umieszczenia zdjęcia w galerii jest ich korzystny na nim wygląd.

Osiem respondentek wyznało, że podobają im się fotografie opublikowane przez ich znajomych. Pięć z nich nie wpisało uzasadnienia. Natomiast rdzeniem uzyskanej argumentacji okazał się dla respondentek inspirujący charakter zdjęcia i jego unikatowość ze względu na możliwość spojrzenia na świat oczami swoich bliskich. Pozostałym dwóm ankietowanym zdjęcia znajomych osób nie podobają się. Zdaniem jednej z badanych, głównym powodem jest niski poziom merytoryczno-estetyczny tych fotografii. Druga z kolei, posługując się prawdopodobnie mową potoczną, uznała je za słabe, czyli pozbawione jakichkolwiek walorów.

Pięć respondentek zadeklarowało, że komentarze, umieszczane pod ich zdjęciami, nie mają żadnego znaczenia. Jedna z ankietowanych uznała za ważne tylko uwagi od osób bliskich, które przy tym stanowią dowód na zainteresowanie jej osobą. Podobne stanowisko wyraziła inna respondentka - jej zdaniem komentarz jest miernikiem zaangażowania w relację z nią. Kolejna ankietowana powiązała z krótką notką pod zdjęciem swoje (odczuwane w konkretnej chwili) samopoczucie. 
$60 \%$ ankietowanych uznało, że fotografie publikowane na portalu społecznościowym mogą mieć wpływ na postrzeganie osoby w świecie rzeczywistym (rzeczywistym w rozumieniu - niewirtualnym). Dominującym uzasadnieniem tego stanowiska jest przekonanie, że zdjęcia odzwierciedlają osobowość osób na nich uwiecznionych. Pojawiła się też opinia stojąca w opozycji do powyższej argumentacji. Jedna z respondentek uznała, iż fakt wybiórczego publikowania zdjęć ukazuje pozbawione szerszego kontekstu rejestry wydarzeń, wobec tego nie daje żadnych informacji na temat charakteru. Z drugiej strony, przyznała, że pomimo wszystko odbiorcy budują obraz osoby na podstawie tych wyselekcjonowanych fotografii. Jedna respondentka uznała, iż nie dostrzega wpływu zdjęć na postrzeganie człowieka, gdyż poznali jq̨ i na tej podstawie wydają sądy. 30\% ankietowanych nie udzieliło jednoznacznej odpowiedzi na to pytanie.

\subsubsection{Pozostałe pytania - mężczyźni}

Na pytanie dotyczące posiadania profilu fikcyjnego jeden respondent w tej grupie wiekowej odpowiedział twierdząco. Jego głównym argumentem jest chęć dostępu do informacji na temat odwiedzin jego profilu oficjalnego, przy zachowaniu możliwości przeglądania różnych kont bez wiedzy ich właścicieli. Reszta respondentów odpowiedziała negatywnie na powyższe pytanie. Głównym uzasadnieniem jest to, że ankietowani nie odczuwają potrzeby posiadania profilu fikcyjnego bądź podważają sens istnienia takiej opcji. Inny argument dotyczył tego, że respondenci postrzegają siebie jako osoby niefikcyjne, wobec czego nie zamierzają z tej oferty portalu nasza-klasa.pl skorzystać.

Najważniejszymi przesłankami, decydującymi o wyborze zdjęć do publikacji, są: ich jakość, atrakcyjność i aktualność. Jeden z ankietowanych zaznaczył, że udostępnione fotografie muszą być na tyle stonowane, aby można je było pokazać każdej osobie. Dwóch respondentów podkreśliło istotną rolę ich partnerek w wyborze zdjęć.

Siedmiu ankietowanych w tej grupie mężczyzn uznało zdjęcia swoich znajomych za atrakcyjne. Głównym uzasadnieniem jest fakt, że respondenci mogą mieć wgląd w aktualne wydarzenia w życiu bliskich im osób. Czterech ankietowanych nie uzasadniło tego stanowiska. 30\% respondentów zadeklarowało, iż zazwyczaj nie podobają im się zdjęcia ich zna- 
jomych. Jeden z ankietowanych wyznał, że trudno wywołać u niego pozytywne wrażenie lub emocje za pomocą zdjęcia.

Pytanie dotyczące ważności komentarzy ujawniło następującą argumentację - kilku respondentów stwierdziło, że notka pod zdjęciem nie ma dla nich znaczenia. Inni dodali przy tym, że zazwyczaj otrzymują komentarze banalne i nieszczere. Kilku ankietowanych udzieliło niejednoznacznej odpowiedzi, stwierdzając, z jednej strony, istotność tych uwag, a z drugiej - jej kompletny brak.

Na pytanie nawiązujące do wpływu zdjęć na postrzeganie osoby zaledwie trzech respondentów udzieliło jednoznacznej odpowiedzi. Dwóch uznało, że taka influencja może zaistnieć. Jeden z nich uzasadnił, że poprzez zdjęcia może wyrazić siebie (jeden respondent wyraził brak chęci opisania swoich refleksji). Jeden ankietowany zajął stanowisko przeciwne, nie podając jednakże argumentacji. Siedmiu mężczyzn zdecydowało się zaznaczyć odpowiedź trudno powiedzieć.

\subsection{Grupa wiekowa 19-24 lata}

\subsubsection{Pytania zamknięte - kobiety i mężczyźni}

Najwięcej kobiet i mężczyzn w tej grupie wiekowej ma konto od roku. Jednocześnie wszyscy zadeklarowali, że pamiętają, kiedy je sobie założyli ( $0 \%$ wśród kobiet i mężczyzn dla odpowiedzi: nie pamiętam). Kobiety najczęściej logują się na swoim koncie kilka razy dziennie, podobnie jak mężczyźni (ex aequo wybrano odpowiedź kilka razy dziennie i raz dziennie). Zdecydowana większość pań i panów ma tylko jeden album w galerii. Znamienna część osób w tej grupie udostępniła zdjęcia wszystkim użytkownikom portalu www.nasza-klasa.pl (galeria otwarta). Najwięcej kobiet posiada od 21 do 50 zdjęć, z kolei najliczniejsza grupa wśród mężczyzn posiada ich między 11 a 20. Większa część ankietowanych, bez względu na płeć, publikuje zdjęcia kilka razy w roku. Są to najczęściej fotografie przedstawiające wizerunek respondenta (zarówno u mężczyzn, jak i kobiet), jednakże panowie często wskazywali na odpowiedź spotkania. Większość kobiet i mężczyzn w tej grupie wiekowej wpisuje w opisie zdjęcia coś zabawnego. Znacząca część pań nie zamieszcza zdjęć, na których wygląda, wedle własnego uznania, niekorzystnie. Niejednoznaczne stanowisko zajęli pa- 
nowie - 40\% wybrało odpowiedź tak, z drugiej jednak strony tyle samo zaznaczyło trudno powiedzieć. Większość respondentek i respondentów nie używa programów do obróbki graficznej w celu wyretuszowania swoich zdjęć przed publikacją. Duża część kobiet zadeklarowała, że nie odwiedza profili osób im nieznanych. Odwrotnie zadeklarowali mężczyźni. Większość, bez względu na płeć, nigdy nie komentuje zdjęć osób obcych. Wszyscy badani w tej grupie zadeklarowali nieistotność ocen, jakie są wystawiane ich fotografiom. Podobny stosunek respondenci mają do poddawania ocenie zdjęć swoich znajomych - znaczna część z nich tego nie robi. Kobiety komentują fotografie osób im znanych czasami, z kolei mężczyźni rzadko. Większość pań zadeklarowała, że raz w roku, raz na kilka miesięcy i kilka razy w miesiqcu odwiedza profile wszystkich swoich znajomych, co oznacza, iż znacząca część jednak wykonuje tę czynność - w przeciwieństwie do panów, z których siedmiu na dziesięciu nie robi tego nigdy. Badane kobiety zajęły niejednoznaczne stanowisko względem publikowania zdjęć $z$ ich wizerunkiem przez swoich znajomych, z kolei ankietowani mężczyźni, w większości, nie mają nic przeciwko temu.

\subsubsection{Pozostałe pytania - kobiety}

Na pytanie dotyczące posiadania konta fikcyjnego 10\% kobiet zaznaczyło odpowiedź tak, z kolei $90 \%$ - nie. Uzasadnienia prezentują się następująco - respondentka, która potwierdziła posiadanie konta fikcyjnego, umotywowała to stwierdzeniem, że chce mieć możliwość odwiedzania profili bez wiedzy ich właścicieli. Wśród uzasadnień odpowiedzi przeczącej najczęściej podawany był argument, iż konto fikcyjne jest niepotrzebne.

Pytanie dotyczące motywów, jakimi kierują się respondentki z tej grupy wiekowej, wyłuszczyło następujące przesłanki, decydujące o publikacji: atrakcyjny wygląd na zdjęciu, potencjalnie ciekawa tematyka zdjęcia, a także chęć bycia identyfikowaną ze swoim nazwiskiem (gdyby znajomi respondentki chcieli ją odszukać w zasobach portalu).

Pytanie o to, czy ankietowanym paniom podobają się fotografie umieszczane przez ich znajomych, 90\% wybrało odpowiedź zazwyczaj tak, przy czym trzy z nich nie podały uzasadnienia. Z zarejestrowanych wyjaśnień, przemawiających za odpowiedzią twierdzącą, najczęściej występował argument, że zdjęcia te respondentki uznają za ciekawe i zabawne. 
Pojawiła się jedna odpowiedź w ramach tego stanowiska, iż fotografie zazwyczaj podobają się, gdyż nie są kompromitujące. Jedna osoba uznała, że zdjęcia zazwyczaj jej się nie podobają, ponieważ są tendencyjne.

Na pytanie o to, jakie znaczenie mają dla respondentek komentarze, wpisywane pod ich własnymi zdjęciami, połowa z nich przedstawia uzasadnienie, że są one wyrazem sympatii. Natomiast druga połowa zadeklarowała, iż nie mają one żadnej wartości.

Ostatnie pytanie, z możliwością uzasadnienia, stanowiło prośbę o refleksję, czy zdjęcia zamieszczane na portalu www.nasza-klasa.pl mają wpływ na to, jak użytkownicy są postrzegani w rzeczywistości. Do wyboru były trzy odpowiedzi: tak i nie, z możliwością uzasadnienia, oraz trudno powiedzieć. $60 \%$ respondentek stwierdziło, że zdjęcia wpływają na wizerunek, a najczęstszym argumentem za tym stanowiskiem był fakt, iż pokazują one aktualne zmiany w życiu respondentki, przez co znajomi mogą budować określony obraz jej osoby. Jedna badana kobieta udzieliła odpowiedzi przeczącej, bagatelizując znaczenie profilu na portalu społecznościowym. 30\% zaznaczyło odpowiedź trudno powiedzieć.

\subsubsection{Pozostałe pytania - mężczyźni}

Na pytanie dotyczące posiadania konta fikcyjnego twierdząco odpowiedział jeden mężczyzna, uzasadniając to możliwością przeszukiwania zasobów portalu w celu odnalezienia znajomych. Jednakże $90 \%$, które zadeklarowało brak takiego konta, jako główny argument podało brak potrzeby. Jeden respondent stwierdził, że posiadanie nieprawdziwego profilu stanowi fikcję $w$ fikcji.

Pytanie o motywację przy doborze zdjęć do publikacji zaowocowało zróżnicowanymi odpowiedziami. Kilku respondentów jako główny powód umieszczenia fotografii w galerii wskazało potencjalnie ciekawą tematykę na nich uwiecznioną. Dwóch ankietowanych odniosło się do kwestii umożliwienia identyfikacji, natomiast reszta uzależniła dobór fotografii do publikacji od tego, czy zdjęcie im się podoba. Jeden z respondentów zadeklarował, że motywuje go głównie lans, czyli możliwość maksymalnego wyeksponowania swojej osoby i każdego aspektu z nią związanego, prawdopodobnie w celu zaimponowania otoczeniu (warto zauważyć, iż każda jednostka może dążyć do tego celu innymi drogami). 
Kolejne pytanie dotyczyło tego, czy respondentom podobają się zdjęcia ich znajomych. Wszyscy odpowiedzieli twierdząco (dwóch nie uzasadniło), argumentując, że mogą dzięki temu uczestniczyć (jako widzowie) w życiu znanych im osób.

Na zapytanie o znaczenie komentarzy pod ich zdjęciami siedmiu respondentów odpowiedziało, że nie są one istotne. Natomiast trzech z nich określiło je, podobnie jak ankietowane $z$ tej grupy wiekowej, jako miłe.

Pytanie o wpływ zdjęć na postrzeganie respondenta zaowocowało $\mathrm{w} 70 \%$ odpowiedzią trudno powiedzieć. Jeden respondent zadeklarował stanowisko twierdzące, wyjaśniając, że osoby obce mogą na podstawie zdjęć przypisać mu określone cechy, jednak dodał przy tym, iż nie ma to dla niego większego znaczenia. Dwóch ankietowanych odpowiedziało przecząco, uzasadniając, że fotografie przekazują niewiele informacji na temat osoby, a także deklarując nieprzywiązywanie wagi do cudzych opinii.

\subsection{Grupa wiekowa $25-40$ lat}

\subsubsection{Pytania zamknięte - kobiety i mężczyźni}

Najwięcej kobiet zbadanych w tej grupie wiekowej ma konto od 4 lub, jak większość mężczyzn, od 2 lat. Panie logują się na swoim koncie zazwyczaj kilka razy $w$ tygodniu (niewiele mniej raz dziennie), natomiast panowie raz dziennie. Zdecydowana większość ankietowanych w tej grupie wiekowej posiada w swojej galerii jeden album. Połowa kobiet ma galerię zamknięta, druga połowa otwarta, podobnie jak większość mężczyzn. Ankietowane $w$ tej grupie panie posiadają zróżnicowaną liczbę zdjęć - każdy z dostępnych przedziałów został wybrany przez jedną lub dwie respondentki. Połowa panów zadeklarowała opublikowanie od 6 do 10 fotografii. Zdecydowana większość kobiet umieszcza w galerii swoje zdjęcia kilka razy w roku. Tę samą częstotliwość wybrała połowa mężczyzn. Dziewięć na dziesięć respondentek jest obecnych na swoich własnych zdjęciach, identyczna proporcja występuje w przypadku badanych mężczyzn. Dodatkowo, połowa pań zadeklarowała publikację fotografii ze spotkań (np. imprez). W opisie pod zdjęciami większość kobiet wpisuje fakt z nimi związany, na przykład datę lub miejsce wykonania. Połowa ankietowanych pań wybrała także odpowiedź coś zabawnego, tak samo jak większość mężczyzn. Czterech 
na dziesięciu respondentów zadeklarowało również wariant fakty. Połowa kobiet nie zamieszcza zdjęć, na których prezentuje się, we własnym mniemaniu, niekorzystnie. Pozostałe nie zajęły jednoznacznego stanowiska w tej kwestii. Połowa badanych mężczyzn publikuje takie zdjęcia, trzech na dziesięciu tego nie robi, a dwóch pozostało obojętnych. Zdecydowana większość kobiet i mężczyzn umieszcza zdjęcia niepoddane obróbce graficznej. Odpowiedzi na pytanie, dotyczące odwiedzin profili osób nieznajomych, były dość zróżnicowane - cztery panie wykonują tę czynność, trzy nie. Pozostałe ankietowane warunkowo przeglądają konta nieznajomych, jednakże przy okazji poszukiwań swoich znajomych. Z kolei połowa panów odwiedza profile osób obcych, lecz czterech wykonuje to w trybie opisanym w poprzednim zdaniu. Wobec tego można przyjąć, że zdecydowana większość mężczyzn w tej grupie wiekowej wykonuje omawianą czynność. Znaczna część kobiet nie komentuje nigdy zdjęć osób nieznajomych, proporcjonalnie taka sama liczba panów robi to rzadko. Oceny fotografii respondentów w tej grupie wiekowej nie są dla większości z nich istotne (wniosek wynikający z odpowiedzi obydwu płci). Ośmiu na dziesięciu mężczyzn komentuje zdjęcia swoich znajomych. Kobiety odpowiedziały w połowie twierdząco i przecząco. Ponadto znaczna część ankietowanych pań czasami komentuje zdjęcia znajomych. Połowa mężczyzn wykonuje tę czynność rzadko. Pięć na dziesięć respondentek odwiedza profile wszystkich znajomych raz na kilka miesięcy, z kolei czterech respondentów $w$ tej grupie wiekowej nie robi tego wcale.

\subsubsection{Pozostałe pytania - kobiety}

Na pytanie dotyczące posiadania konta fikcyjnego wszystkie badane w tej grupie wiekowej kobiety odpowiedziały przecząco. Dwoma dominującymi uzasadnieniami był fakt, że takiego profilu ankietowane nie potrzebują lub też nie odczuwają potrzeby ukrywania się. Pojawiła się też odpowiedź, iż nie ma konieczności udawania kogoś innego.

Pytanie nawiązujące do tego, jakimi przesłankami kierują się ankietowane podczas wyboru zdjęć do publikacji portalu www.nasza-klasa.pl, ujawniło zróżnicowane motywy. Każda z badanych kobiet odpowiedziała inaczej. Jedna z respondentek nie kieruje się niczym szczególnym w wyborze zdjęć, inna kontroluje tematykę zdjęć, aby wyglądać na nich w miarę 
normalnie. Inne uzasadnienia: mam jedno zdjęcie legitymacyjne, nie wrzucam zdjęć co tydzień i się nie lansuję; muszą być normalne tzn. - nieordynarne czy wyzywające, czy też prowokujące; przede wszystkim bardzo rzadko zmieniam zdjęcia w mojej galerii; umieszczam zdjęcia, na których znajduję się ja i moi przyjaciele - z różnych wspólnych przedsięwzięć. Kolejne respondentki kierują się emocjami, atrakcyjnością fotografii i tym, czy korzystnie na nich wyglądają. Jedna z badanych publikuje zdjęcia ilustrujące ważne wydarzenie (lub samą chwilę). Ostatnia z argumentacji dotyczyła zamieszczania fotografii dla swoich znajomych, z którymi ankietowane nie mają częstego kontaktu.

Zapytanie, czy zdjęcia publikowane przez znajomych badanych kobiet podobają im się, otrzymało 100\% odpowiedzi twierdzących. Pięć respondentek nie uzasadniło wyboru swojej odpowiedzi. Z kolei argumentem dominującym była możliwość wglądu w wydarzenia, w których znajomi ankietowanych uczestniczyli.

Zapytanie, nawiązujące do stosunku respondentek do komentarzy pod ich zdjęciami, dało następujące wyniki - trzy panie wyznały, że cudza adnotacja pod zdjęciem nie ma dla nich znaczenia. Inne stwierdziły, iż te krótkie uwagi są przyjemne, gdyż zazwyczaj mają formę komplementu. Są także zabawne oraz mogą podnieść na duchu.

Na pytanie o wpływ zdjęć na postrzeganie respondentek 40\% pań potwierdziło zawartą w pytaniu tezę. Dwie nie uzasadniły swojego stanowiska. Otrzymane argumentacje nawiązywały do skłonności odbiorców (pojmowanych jako osoby odwiedzające profil respondentek) do oceny osób, które swoje fotografie umieszczają w zasobach sieci. Pozostałe nie zajęły jednoznacznego stanowiska.

\subsubsection{Pozostałe pytania - mężczyźni}

100\% ankietowanych mężczyzn nie ma konta fikcyjnego. W swoim uzasadnieniu respondenci akcentowali brak takiej potrzeby. Jeden $z$ ankietowanych podkreślił, że nie jest osobą fikcyjną, z kolei inny wzmocnił wybraną przez siebie odpowiedź lakonicznym stwierdzeniem: bo nie.

Niczym szczególnym, przedmiotem zdjęcia i jego estetyką, związkiem ze szkołą, własną atrakcyjnością - tymi motywami kierowali się ankietowani mężczyźni w odpowiedzi na pytanie, jakie przesłanki decydują 
o wyborze konkretnych fotografii do publikacji na portalu nasza-klasa.pl. Jeden z respondentów wyznał, że decydującym czynnikiem jest format. Stanowi to niejako miernik umiejętności ( $w$ tym przypadku - niewielkich) obsługi podstawowych programów, oferujących możliwość edycji zdjęć. Inny respondent na postawione pytanie odpowiedział, że opublikował jedyne zdjęcie, jakie w ogóle posiadał.

Wszyscy ankietowani stwierdzili, że podobają im się zdjęcia zamieszczane przez znajomych. Niektórzy argumentowali to tym, że fotografie są zabawne, fajne i pokazujq obecne życie znajomych. Jeden z mężczyzn, jako uzasadnienie, podał stwierdzenie to moi znajomi, inny z kolei wyznał, że zdjęcia te majq wartość dodanq̨. Pojawiła się też odpowiedź nawiązująca do uzależnienia atrakcyjności fotografii od jakości jej wykonania.

Sześciu na dziesięciu ankietowanych zadeklarowało, że komentarze wpisywane pod ich zdjęciami nie są dla nich w żaden sposób istotne. Jeden z badanych stwierdził, że mogą być zaczątkiem do zabawnej konwersacji, inny zadeklarował, iż sprawiają mu przyjemność. Jako odpowiedź na to pytanie jeden z respondentów wpisał wyraz dźwiękonaśladowczy, oznaczający rozbawienie.

Wpływ zdjęć na wizerunek zadeklarowało trzech respondentów. Dwóch z nich nie wpisało uzasadnienia. Jedynym argumentem za odpowiedzią twierdzącą był fakt, że fotografie opublikowane na portalu nasza-klasa.pl stanowią ważne źródło informacji na temat jego użytkowników. Pozostali respondenci nie zajęli jednoznacznego stanowiska.

\subsection{Kobiety w przedziale wiekowym 41-59 lat}

\subsubsection{Pytania zamknięte}

Najwięcej respondentek posiada swoje konto stosunkowo długo, założyło je bowiem rok po uruchomieniu portalu nasza-klasa.pl. Większość loguje się na swoim koncie raz dziennie, co stanowi dużą aktywność. Znaczna część pań ma tylko jeden album w swojej galerii. Większość udostępniła swoje albumy wszystkim odwiedzającym ich profil. Znaczna część pań posiada powyżej 100 zdjęć w swojej galerii. Po trzy respondentki wybrały następujące częstotliwości publikacji fotografii: raz $w$ roku, kilka razy $w$ roku, kilka razy $w$ miesiącu. Wszystkie ankietowane $w$ tej grupie umiesz- 
czają zdjęcia, na których same się znajdują. Zdecydowana część publikuje fotografie swojej rodziny, nieco mniej niż połowa - małżonka. Co się tyczy opisów zdjęć, większa część wpisuje pod nimi fakty (np. datę, miejsce wykonania zdjęcia, osoby znajdujące się na nim). Nieco mniej pań opisuje fotografie za pomocą zabawnego sformułowania lub całkowicie powstrzymuje się od umieszczania jakiegokolwiek opisu. Większość respondentek nie publikuje zdjęć, na których, we własnym mniemaniu, prezentuje się niekorzystnie. Zarazem wszystkie ankietowane kobiety nie używają programów do obróbki zdjęć. Połowa respondentek odwiedza profile osób obcych, nieco mniej decyduje się na skomentowanie fotografii nieznajomego użytkownika. Większość kobiet nie przywiązuje wagi do ocen, które są wystawiane ich zdjęciom. Znaczna część również nie podejmuje się oceniania zdjęć swoich znajomych. Większość pań komentuje fotografie znajomych czasami lub wręcz rzadko. Raz na kilka miesięcy większa część respondentek odwiedza profile swoich znajomych. Większość kobiet w tej grupie wiekowej nie akceptuje publikacji zdjęć, na których jest uwieczniona, bez uprzedniego zapytania o zgodę.

\subsubsection{Pozostałe pytania}

Żadna z ankietowanych w tej grupie kobiet nie posiada konta fikcyjnego. Uzasadnieniem takiego stanu rzeczy okazały się dwa główne powody - respondentki nie odczuwają potrzeby posiadania profilu, który nie jest ich kontem oficjalnym i zgodnym z szeroko rozumianymi danymi osobowymi. Drugim powodem jest postrzeganie kont fikcyjnych jako sposobu na ukrycie tożsamości, co nie odpowiada ankietowanym w tej grupie paniom.

Na pytanie dotyczące motywów, jakimi kierują się respondentki przy wyborze zdjęć do publikacji na naszej-klasie.pl, trzy kobiety zadeklarowały, że najważniejsze są dla nich fotografie przedstawiające najbliższą rodzinę. Kolejne trzy respondentki uznały za czynnik decydujący aktualność. Inne przesłanki to atrakcyjność własna i zdjęcia. Jedna z respondentek odpowiedziała, iż kieruje się bezpieczeństwem. Prawdopodobnie może to oznaczać, że ta konkretna ankietowana stara się tak dobierać zdjęcia do publikacji, aby nie stanowiły one zagrożenia dla osób na nich uwiecznionych lub nie zostały użyte w niewłaściwych celach. 
70\% kobiet wyznało, że podobają im się zdjęcia opublikowane przez ich znajomych. Wśród zadeklarowanych uzasadnień dominują dwa - możliwość uczestnictwa $w$ aktualnych wydarzeniach oraz wspominania wspólnych przeżyć. Dla jednej z respondentek istotny był też fakt, iż może, poprzez swoje konto, poznać rodzinę osoby znajomej. Pozostałym trzem ankietowanym nie podobają się zdjęcia opublikowane przez ich znajomych. Respondentki uargumentowały swoje stanowisko w następujący sposób - fotografie zostały uznane za nieatrakcyjne, gdyż nie przedstawiają danej osoby, są zbyt wyzywające oraz ukazują wizerunek rodziny idealnej, która faktycznie (w mniemaniu respondentki) taka nie jest.

$\mathrm{Na}$ pytanie dotyczące istotności komentarzy, które respondentki otrzymują od swoich znajomych, padły następujące odpowiedzi - trzy ankietowane kobiety stwierdziły, że mają one duże znaczenie, dwie kolejne zadeklarowały, iż nie są dla nich ważne. Podobne stanowisko do poprzedniego zajęły również dwie panie, przy czym dodały, że jednak sprawiają im przyjemność. Jedna z respondentek wyznała, że lubi je otrzymywać, gdy ma pewność co do ich szczerości. Reszta pań uzasadniła, że stanowią po prostu okazję do wyartykułowania swojego zdania.

Trzy respondentki wyznały, że zdjęcia, które publikuje się na portalu społecznościowym, mogą mieć wpływ na postrzeganie ich właściciela. Dwie panie podały następujące uzasadnienie - fotografie są ważne w procesie tworzenia wizerunku, ponieważ stanowią wizytówkę osoby na nich występującej oraz (uzasadnienie drugiej respondentki) pozwalają na wgląd w bieżące wydarzenia w ich życiu. Dwie respondentki stwierdziły, że zdjęcia nie mają wpływu na ich postrzeganie przez osoby odwiedzające ich profile - uzasadnieniem jest fakt, iż jedna z pań zawsze jest sobq, a druga z kolei zaznaczyła, że znajomi nie poznają jej za pomocą zdjęć.

\subsection{Mężczyźni w przedziale wiekowym 41-64 lata}

\subsubsection{Pytania zamknięte}

Prawie połowa ankietowanych w tej grupie wiekowej mężczyzn założyła swoje konto 2 lata temu. Pozostali mężczyźni posiadają je jeszcze dłużej. Panowie logują się na swoim koncie najrzadziej raz w miesiącu, a najczęściej raz dziennie. Zdecydowana większość posiada jeden al- 
bum w galerii, natomiast wszyscy udostępnili ją dla każdego odwiedzającego użytkownika www.nasza-klasa.pl. Liczba publikowanych zdjęć okazała się w tej grupie wiekowej zróżnicowana, najwięcej mężczyzn zamieszcza od 2 do 5 fotografii. Ponad połowa ankietowanych umieszcza zdjęcia w galerii kilka razy w roku. Prawie wszyscy publikują własne zdjęcia. Połowa ankietowanych do opisu fotografii stosuje fakty, np. datę lub miejsce wykonania. Połowa badanych w tej grupie wiekowej nie publikuje zdjęć, na których, wedle własnego odczucia, prezentuje się niekorzystnie. Jednakowo żaden z ankietowanych nie zamieszcza fotografii obrobionych w programie graficznym typu Photoshop. Odwiedziny profili osób obcych respondentom mają charakter przypadkowy i są rezultatem poszukiwań znajomych użytkowników portalu. Co się tyczy komentowania zdjęć nieznajomych, ankietowani zadeklarowali, że zdarza im się to rzadko. Większość mężczyzn nie postrzega jako istotne ocen, które są wystawiane ich fotografiom. Natomiast na pytanie, czy sami oceniają zdjęcia znajomych, znaczna część nie potrafiła odpowiedzieć. Zaledwie trzech respondentów nie komentuje fotografii osób im znanych. Przy tym czterech badanych nigdy nie odwiedza profili wszystkich swoich znajomych. Ostatnie pytanie, dotyczące publikacji zdjęć przedstawiających respondenta bez jego zgody, ujawniło bardzo zróżnicowane poglądy na tę kwestię.

\subsubsection{Pozostałe pytania}

Żaden $z$ ankietowanych w tej grupie mężczyzn nie ma konta fikcyjnego (przy czym czterech panów nie uzasadniło swojego stanowiska). Rdzeniem argumentacji jest brak odczuwania potrzeby uruchomienia takiego profilu, a także uznawanie tej opcji portalu www.nasza-klasa.pl za niepoważną.

Do głównych przesłanek, które decydują o publikacji konkretnego zdjęcia, panowie w tej grupie zaliczyli: możliwość identyfikacji, atrakcyjność zdjęcia oraz własna, jakość. Jeden z ankietowanych stwierdził, że nie publikuje fotografii. Może to świadczyć o niezrozumieniu pytania lub nieposiadaniu zdjęć w galerii.

Dziewięciu respondentów w tym przedziale wiekowym wyznało, że zazwyczaj podobają im się fotografie zamieszczone przez ich znajo- 
mych. Spośród pięciu wpisanych uzasadnień najczęściej występującym jest możliwość zobaczenia bliskich osób, co ma dla respondentów wymiar osobisty. Jeden z badanych przyznał, że zdjęcia mu się nie podobają, ponieważ są widokówkami, a nie przedstawiają osób, które są właścicielami kont.

Czterech ankietowanych stwierdziło nieważność komentarzy, umieszczanych pod ich fotografiami. Inni wyznali, że uwaga pod zdjęciem może stanowić miernik zainteresowania lub zwyczajną przyjemność. Dwóch badanych mężczyzn stwierdziło, że nie podobają im się komentarze, które mają na celu przypodobanie się im. Jeden ankietowany zaznaczył, że jego galeria na www.nasza-klasa.pl jest pusta.

20\% badanych mężczyzn dostrzega wpływ, jaki wywierają zdjęcia na ich recepcję. Powody są całkowicie odmienne. Jeden respondent uznał, że odbiorcy fotografii utożsamiają je z osobą. Z kolei drugi podkreślił, że zdjęcie może wskazywać na charakter jego zainteresowań. Następne $20 \%$ badanych wyznało, że nie widzą związku między fotografią umieszczoną na profilu na portalu społecznościowym a postrzeganiem osoby. Jedno jedyne uzasadnienie nawiązywało do nieposiadania ani jednego zdjęcia w galerii. Pozostali ankietowani (tj. 60\%) nie udzielili jednoznacznej odpowiedzi na to pytanie.

\subsection{Preferencje kobiet i mężczyzn - pytania zamknięte}

Wszyscy ankietowani, zarówno kobiety, jak i mężczyźni, wybierali najczęściej te same odpowiedzi. Poniższa tabela ukazuje tendencje, które były konsekwentnie zauważalne w wynikach dla pytań zamkniętych. W kwestii zsumowania największej liczby wskazań na daną odpowiedź wystąpiły też wyjątki. Przykładowo na pytanie dotyczące publikacji zdjęć, na których respondenci wyglądają, we własnym odczuciu, niekorzystnie, większa liczba wskazań wystąpiła dla odpowiedzi tak (więcej o jedno wskazanie) aniżeli nie. Jednakże w ostatecznej sumie wskazań ta konkretna odpowiedź (nawiązując do przykładu - odpowiedź nie) uzyskała ich największą liczbę. 
Tabela 2. Najczęściej wybierane odpowiedzi

\begin{tabular}{|c|c|c|c|c|}
\hline Pytanie & $\begin{array}{c}\text { Najczęściej } \\
\text { wybierana odpowiedź }\end{array}$ & Kobiety & Mężczyźni & Suma \\
\hline Jak długo ma Pani/Pan profil na naszej-klasie.pl? & c) od 2 lat & 18 & 22 & 40 \\
\hline $\begin{array}{l}\text { Jak często sprawdza Pani/Pan swój profil na naszej- } \\
\text {-klasie.pl? }\end{array}$ & d) kilka razy w tygodniu & $12^{a}$ & 15 & 27 \\
\hline Ile albumów ma Pani/Pan w galerii? & a) 1 & 42 & 45 & 87 \\
\hline Czy Pani/Pana galeria jest otwarta? & a) otwarta & 32 & 41 & 73 \\
\hline $\begin{array}{l}\text { Jak dużo zdjęć zamieściła Pani/Pan w swojej } \\
\text { galerii? }\end{array}$ & c) $6-10$ & $10^{b}$ & $14^{c}$ & 24 \\
\hline $\begin{array}{l}\text { Jak często zamieszcza Pani/Pan zdjęcia w swojej } \\
\text { galerii na naszej-klasie.pl? }\end{array}$ & b) kilka razy w roku & 25 & 26 & 51 \\
\hline $\begin{array}{l}\text { Co najczęściej przedstawiają zamieszczone przez } \\
\text { Panią/Pana zdjęcia? (pytanie z możliwością wielo- } \\
\text { krotnego wyboru odpowiedzi) }\end{array}$ & a) mnie & 37 & 46 & 83 \\
\hline $\begin{array}{l}\text { Co zazwyczaj wpisuje Pani/Pan w opisie zdjęcia } \\
\text { umieszczonego na naszej-klasie.pl? (pytanie z moż- } \\
\text { liwością wielokrotnego wyboru odpowiedzi) }\end{array}$ & $\begin{array}{l}\text { a) fakty } \\
\text { b) cośzabawnego }\end{array}$ & $\begin{array}{l}20 \\
22\end{array}$ & $\begin{array}{l}20 \\
19\end{array}$ & $\begin{array}{l}40 \\
41\end{array}$ \\
\hline $\begin{array}{l}\text { Czy zdarza się Pani/Panu zamieścić zdjęcie, na } \\
\text { którym nie wygląda Pani/Pan korzystnie? }\end{array}$ & b) nie & 25 & $17^{d}$ & 42 \\
\hline $\begin{array}{l}\text { Czy zdjęcia, które zamieszcza Pani/Pan w galerii na } \\
\text { naszej-klasie.pl, są retuszowane? (np. za pomocą } \\
\text { Photoshopa, GIMPa itp.) }\end{array}$ & b) nie & 33 & 38 & 71 \\
\hline $\begin{array}{l}\text { Czy odwiedza Pani/Pan profile osób Pani/Panu } \\
\text { obcych? }\end{array}$ & $\begin{array}{l}\text { a) tak } \\
\text { c) czasami tak, jako } \\
\text { skutek poszukiwań osób } \\
\text { mi znanych }\end{array}$ & $\begin{array}{l}18 \\
17\end{array}$ & $\begin{array}{l}23 \\
20\end{array}$ & $\begin{array}{l}41 \\
37\end{array}$ \\
\hline $\begin{array}{l}\text { Jak często zdarza się Pani/Panu ocenić/skomento- } \\
\text { wać zdjęcie obcej osoby? }\end{array}$ & e) nigdy & 29 & $17^{e}$ & 46 \\
\hline
\end{tabular}

a Ta sama wartość dla odpowiedzi: c) raz dziennie.

b Ta sama wartość dla odpowiedzi: d) 11-20.

c Ta sama wartość dla odpowiedzi: b) 2-5.

${ }^{d}$ Maksymalna liczba wskazań - 18 - na odpowiedź: a) tak.

e Maksymalna liczba wskazań - 21 - na odpowiedź: d) rzadko. 
Tabela 2. Najczęściej wybierane odpowiedzi (ciąg dalszy)

\begin{tabular}{|l|l|c|c|c|}
\hline \multicolumn{1}{|c|}{ Pytanie } & \multicolumn{1}{|c|}{$\begin{array}{c}\text { Najczęściej } \\
\text { wybierana odpowiedź }\end{array}$} & Kobiety & Mężczyźni & Suma \\
\hline $\begin{array}{l}\text { Czy ważne są dla Pani/Pana oceny Pani/Pana } \\
\text { własnych zdjęć? (w skali od 1-5 lub status Super } \\
\text { Zdjęcie) }\end{array}$ & b) nie & 36 & 38 & 74 \\
\hline $\begin{array}{l}\text { Czy ocenia Pani/Pan zdjęcia swoich znajomych? } \\
\text { (w skali od 1-5 lub status Super Zdjęcie) }\end{array}$ & b) nie & 35 & 31 & 66 \\
\hline $\begin{array}{l}\text { Czy komentuje Pani/Pan świeżo dodane zdjęcia } \\
\text { swoich znajomych? }\end{array}$ & c) czasami & 26 & $16^{f}$ & 42 \\
\hline $\begin{array}{l}\text { Jak często odwiedza Pani/Pan profile wszystkich } \\
\text { swoich znajomych? }\end{array}$ & h) nie robię tego wcale & $11^{9}$ & 21 & 32 \\
\hline $\begin{array}{l}\text { Czy akceptuje Pani/Pan fakt dodawania przez Pani// } \\
\text { /Pana znajomych zdjęć, na których się Pani/Pan } \\
\text { znajduje, bez wcześniejszego pytania 0 zgodę? }\end{array}$ & a) tak & $16^{h}$ & 31 & 47 \\
\hline
\end{tabular}

${ }^{f}$ Maksymalna liczba wskazań - 20 - na odpowiedź: d) rzadko.

g Maksymalna liczba wskazań - 16 - na odpowiedź: f) raz na kilka miesięcy.

${ }^{h}$ Maksymalna liczba wskazań - 23 - na odpowiedź: b) nie.

Źródło: opracowanie własne.

\section{Podsumowanie}

W toku analizy danych okazało się, że mężczyźni i kobiety najczęściej wskazywali na niemalże takie same odpowiedzi. Wobec tego prześledzenie tendencji z rozróżnieniem na płeć nie ma wartości poznawczej. W ramach podsumowania, mając na uwadze powyższy rezultat badawczy, stworzono model przeciętnego użytkownika, rezygnując z obranych zmiennych - płci i wieku. Zsumowano głosy oddane na każdą z odpowiedzi. Te warianty, które były najczęściej wybierane, zostaną przypisane do modelu statystycznego użytkownika portalu www.nasza-klasa.pl. W celu większej czytelności modelowy użytkownik będzie opisywany w rodzaju męskim. W nawiasie jako pierwsza została podana liczba zaznaczeń konkretnej odpowiedzi. Każda z tych wartości odnosi się do wartości maksymalnej, jaką stanowi liczba 100. 
Modelowy użytkownik serwisu www.nasza-klasa.pl założył swoje konto 2 lata temu (40/100). Loguje się na nim średnio kilka razy w tygodniu (27/100). Posiada on jeden album w swojej galerii (87/100), która jest otwarta (73/100). Modelowy użytkownik publikuje od 6 do 10 zdjęć (24/100), z częstotliwością kilka razy w roku (51/100). Przedmiotem fotografii zamieszczanych na portalu www.nasza-klasa.pl jest zazwyczaj on sam (83/100). Swoje zdjęcia opisuje za pomocą zabawnej frazy (41/100) lub faktów (40/100). Przeważnie nie publikuje fotografii, na której, we własnym odczuciu, prezentuje się niekorzystnie (42/100). Z drugiej jednak strony nie zamieszcza on zdjęć poddanych retuszowi (71/100). Zdarza mu się odwiedzać profile osób obcych (41/100), także jako skutek poszukiwań znajomych (37/100). Jednakże modelowy użytkownik nie komentuje nigdy zdjęć nieznajomych (46/100). Natomiast czasami zdarza mu się skomentować zdjęcie swoich znajomych (42/100). Nieważne są dla niego oceny jego własnych fotografii (74/100), sam najczęściej nie podejmuje się wykorzystania tej opcji portalu (66/100). Zazwyczaj nie odwiedza on profili wszystkich swoich znajomych (32/100). Akceptuje ponadto publikację zdjęć, na których został uwieczniony, bez uprzedniego zapytania o zgodę (47/100). 